УДК 615.281+615.276]:618.15-002.018.25-091.8:001.57

DOI https://doi.org/10.11603/2312-0967.2019.1.9881

\title{
ДОСЛІДЖЕННЯ ВПЛИВУ ПОТЕНЦІЙНОГО ЛІКАРСЬКОГО ЗАСОБУ 3 ПРОТИЗАПАЛЬНОЮ ТА ПРОТИМІКРОБНОЮ АКТИВНІСТЮ НА СТРУКТУРНІ ЗМІНИ СЛИЗОВОЇ ОБОЛОНКИ ПІХВИ НА МОДЕЛІ ТРАВМАТИЧНОГО ВАГІНІТУ
}

\author{
Л. В. Онищук, І. В. Ніженковська, С. І. Савосько \\ Національний медичний університет імені О.О. Богомольця, Київ \\ lucy.on04@gmail.com
}

\begin{abstract}
Мета роботи. Дослідити структурні зміни слизової оболонки піхви щурів після моделювання травматичного вагініту та впливу комбінованих супозиторіїв з протизапальною та протимікробною активністю.

Матеріали і методи. Тваринам відтворювали модель травматичного вагініту, після чого у піхву вводили досліджувані лікарські засоби у вигляді супозиторіїв. Досліджуваний потенційний лікарський засіб містив ібупрофрен, клотримазол і метронідазол у вигляді супозиторіїв. До складу Нео-Пенотрану ${ }^{\circledR}$ (препарат порівняння) входили міконазол і метронідазол. Обидва лікарські засоби включали ідентичну основу - вітепсол. Матеріалом дослідження були зразки піхви щурів, відібрані для гістологічного дослідження.

Результати й обговорення. При моделюванні травматичного вагініту в щурів спостерігали дистрофічні зміни епітеліоцитів і зменшення товщини слизової оболонки піхви, гіперемію судин, інорільтрацію лейкоцитів, меншою мірою регенерації. Введення досліджуваного потенційного лікарського засобу та препарату порівняння позитивно вплинуло на відновні процеси слизової оболонки піхви. Структурними проявами відновного процесу були проліферативні зміни в епітелії та збільшення щільності фрібробластів у власній пластинці слизової оболонки. Встановлено статистично значуще збільшення товщини епітелію.

Висновки. Зроблено висновок про запобігання дистрофрічним змінам піхви при застосуванні досліджуваного лікарського засобу та препарату порівняння на моделі травматичного вагініту, протекторну дію щодо епітелію слизової оболонки піхви та протизапальну дію ібупрофену в комплексі з протимікробними засобами.
\end{abstract}

Ключові слова: травматичний вагініт; структурні зміни; слизова оболонка; супозиторії.

Вступ. Запальні захворювання статевих органів жінок - актуальна проблема в гінекології [1]. Вагініт може мати як інфекційну (кандидоз, бактеріальну або трихомоніаз), так і неінорекційну етіологію (алергічні реакції, гормональні зміни, супутні системні розлади після терапевтичного лікування або травм після хірургічних втручань) [2]. Слизова оболонка піхви постійно зазнає впливу інсекційних агентів, а розвиток інорекційного процесу може бути стрімким. Місцева імунна відповідь відіграє критичну роль у розвитку структурних змін епітелію слизової оболонки піхви, порушення його бар'єрної фрункції, що характеризується збільшенням кількості макрофрагів, нейтрофрілів і лімфроцитів [3].

Розробка лікарських засобів для лікування вагініту ґрунтується на етіопатогенезі захворювання $[4,5,6]$. Для лікування грибкового вагініту запропоновано інтравагінальне введення імідазолу, клотримазолу та нових синтетичних похідних триазолів [2]. Ефективним методом лікування бактеріальних вагінітів $€$ застосування метронідазолу або тинідазолу [7]. Усі ці засоби мають пряму протигрибкову, антибактеріальну і протипротозойну дію через порушення синтезу компонентів клітинної стінки мікроорганізмів. Для пригнічення місцевої запальної реакції запропоновано ібупрофен [8], який також має антимікробну дію проти грамнегативних штамів, Gardnerella vaginalis, a також Candida albicans [9]. Ібупрофрен має терапевтичні переваги порівняно з іншими НПЗ3 та застосовується у створенні комплексних препаратів, зокрема і для лікування вагінітів $[10,11]$. Ці характеристики дозволили створити комбінований лікарський засіб 3 протизапальною (ібупрофен) та протимікробною (клотримазол, метронідазол) активністю для лікування вагініту різної етіології. Передбачається, що застосування ібупрофрену в даній комбінації може мати перевагу в терапевтичній дії та зменшенні ризику побічної дії від поліпрагмазії [12].

Мета роботи - дослідити структурні зміни слизової оболонки піхви щурів після моделювання травматичного вагініту (ТВ) та впливу комбінованих супозиторіїв із протизапальною та протимікробною активністю.

Матеріали і методи. Дослідження проводили на 35 щурах-самках лінії Wistar масою 200-220 г. Тваринам відтворювали модель травматичного вагініту, яка полягає у проведенні маніпуляцій, що спрямовані на механічне пошкодження слизової оболонки піхви і

ISSN 2312-0967. Pharmaceutical review. 2019. № 1 
Фармакологічні дослідження біологічно активних речовин Pharmacological researches of biologically active substances

розвитку місцевого запалення [13]. Для цього у піхву щурів вводили скарифікатор і 4-5-ма обертовими рухами пошкоджували слизову. Тривалість відтворення моделі складала 5 діб, після чого у піхву вводили досліджувані лікарські засоби. Тварини були розподілені на 5 груп: 1-ша - інтактні тварини (контроль); 2-га - тварини з модельованим травматичним вагінітом; 3-тя - ТВ + основа (О); 4-та - ТВ + новий комбінований досліджуваний препарат із протизапальною та протимікробною активністю у вигляді вагінальних супозиторій (ДП); 5-та - ТВ + референтний препарат Нео-Пенотран ${ }^{\circledR}$ ЕкселтісХелске С.Л., Іспанія у вигляді вагінальних супозиторій (РП). Основа досліджуваного і референтного препаратів була ідентичною - вітепсол. Тривалість введень усіх досліджуваних засобів склала 5 діб. Після завершення експерименту, тобто на 10 добу експерименту, тварин виводили з досліду шляхом швидкої декапітації.

Матеріалом дослідження була піхва контрольної і дослідних груп щурів. Для гістологічного дослідження матеріал фріксували у 10 \% розчині фрормаліну на холодному фоссратному буфері (PBs, pH 7,4). Тривалість фріксації становила 24 години. Зафріксований матеріал промивали у проточній воді, зневоднювали у висхідних концентраціях етанолу і заключали у парафрін (Leica Surgipath Paraplast Regular). Протокол дегідратації: етанол (з 70 \% , 96 \% розчин етанолу), діоксан, ксилол, ксилол/парафін (1:1), парафін. Просякання парафріном здійснювали у термостаті СТ-100 (UOSLab). Парафінові блоки орієнтували таким чином, щоб у проекції гістологічного зрізу була вся площа органа в поперечному перерізі. Парафрінові зрізи товщиною 5 мкм отримували на мікротомі Thermo Microm HM 360. Зрізи депарафрінували, регідратували і забарвлювали гематоксилін-еозином. Мікропрепарати досліджували за допомогою мікроскопа Olympus BX 51. Отримували мікрофотографрії з рандамно відібраних ділянок слизової оболонки. Морфометричний аналіз проведено 3 використанням програмного забезпечення CarlZeiss (AxioVision SE64 Rel.4.9.1) при збільшенні $\times 400$. Кількісна оцінка полягала у вимірюванні товщини слизової оболонки за двома точками: перша - контур епітеліальної пластинки, з просвіту піхви, другий - зовнішній контур епітеліальної пластинки, який межує з власною пластинкою слизової оболонки. 3 кожного зразка вимірювали 10 значень і усереднювали їх у групі. Товщину вимірювали у мкм.
Для оцінки загальноморфологічних змін органа проведено аналіз змін за критеріями: набряк слизової оболонки, гіперемія судин слизової оболонки, крововиливи, лейкоцитарні інфрільтрати (нейтрофріли, моноцити). Кожний з критеріїв оцінено у балах: 1 бал - зміни виявлено у ділянках зразка <25 \% від загальної площі, 2 бали - зміни виявлено у 25-50 \% площі зразка, 3 бали - зміни виявлено у 50-75\% площі зразка. Загальна кількість балів кожного досліджуваного зразка складала суму балів за кожним критерієм. Мінімальна кількість балів - 0, максимальна - 12. Алгоритм оцінки наведено у таблиці 1.

Статистичну оцінку проводили 3 використанням непараметричних методів. Критерій КолмогороваСмірнова використано для визначення правильного розподілу вибірок даних. Міжгрупову різницю визначали за непараметричним критерієм Крускала-Уоліca (Kruskal-Wallis ANOVA). Результати морфометричного дослідження наведено у вигляді медіани (Me) і квартельних інтервалів [Q1-Q3]. Різницю вважали статистично значущою при $\mathrm{P}<0,05$. Вибірки даних аналізували з використанням програмного забезпечення Origin Lab version 8.0.

Усі маніпуляції проведено відповідно до положень Європейської конвенції про захист хребетних тварин, що використовуються для дослідницьких або інших наукових цілей від 18.03.1986 року, Закону України № 3447-IV «Про захист тварин від жорстокого поводження» від 2006 року, Директиви ЄС № 2010/63/ЄС про захист тварин, що використовуються 3 науковою метою від 22.09.2010 року.

Результати й обговорення. У групі з ТВ встановлено структурні зміни слизової та меншою мірою м'язової оболонки. На рисунку 1 показано зміни епітеліальної та власної пластинки слизової оболонки піхви контрольної і дослідних груп. Головними проявами структурних змін при ТВ були: механічна деструкція епітелію, загибель клітин та їх відшарування у просвіт органа, зменшення товщини епітеліальної пластинки. Меншою мірою видно реорганізаційні зміни, які полягали у зміні морфології епітеліоцитів та збільшенні їх щільності, що оцінено як прояв репаративної регенерації. У сполучній тканині власної пластинки, рідше м'язовій оболонці, виявлено осередки гемосидерину, що є продуктом розпаду еритроцитів після травматичного пошкодження слизової оболо-

Таблиця 1. Шкала вимірювань структурних змін піхви

\begin{tabular}{|c|c|c|c|c|c|}
\hline \multirow{2}{*}{ Група } & \multicolumn{5}{|c|}{ Показник } \\
\cline { 2 - 5 } & $\begin{array}{c}\text { набряк слизової } \\
\text { оболонки }\end{array}$ & $\begin{array}{c}\text { гіперемія судин } \\
\text { слизової оболонки }\end{array}$ & крововилив & $\begin{array}{c}\text { лейкоцитарні } \\
\text { інорільтрати }\end{array}$ & Ме [Q1-Q2] \\
\hline 1 & - & - & - & - & 0 \\
\hline 2 & $\mathrm{n}$ & $\mathrm{n}$ & $\mathrm{n}$ & $\mathrm{n}$ & $\Sigma \mathrm{n}$ \\
\hline 3 & $\mathrm{n}$ & $\mathrm{n}$ & $\mathrm{n}$ & $\mathrm{n}$ & $\Sigma \mathrm{n}$ \\
\hline $\mathrm{n}$ & $\mathrm{n}$ & $\mathrm{n}$ & $\mathrm{n}$ & $\mathrm{n}$ \\
\hline
\end{tabular}

ISSN 2312-0967. Фармацевтичний часопис. 2019. № 1 
Фармакологічні дослідження біологічно активних речовин Pharmacological researches of biologically active substances
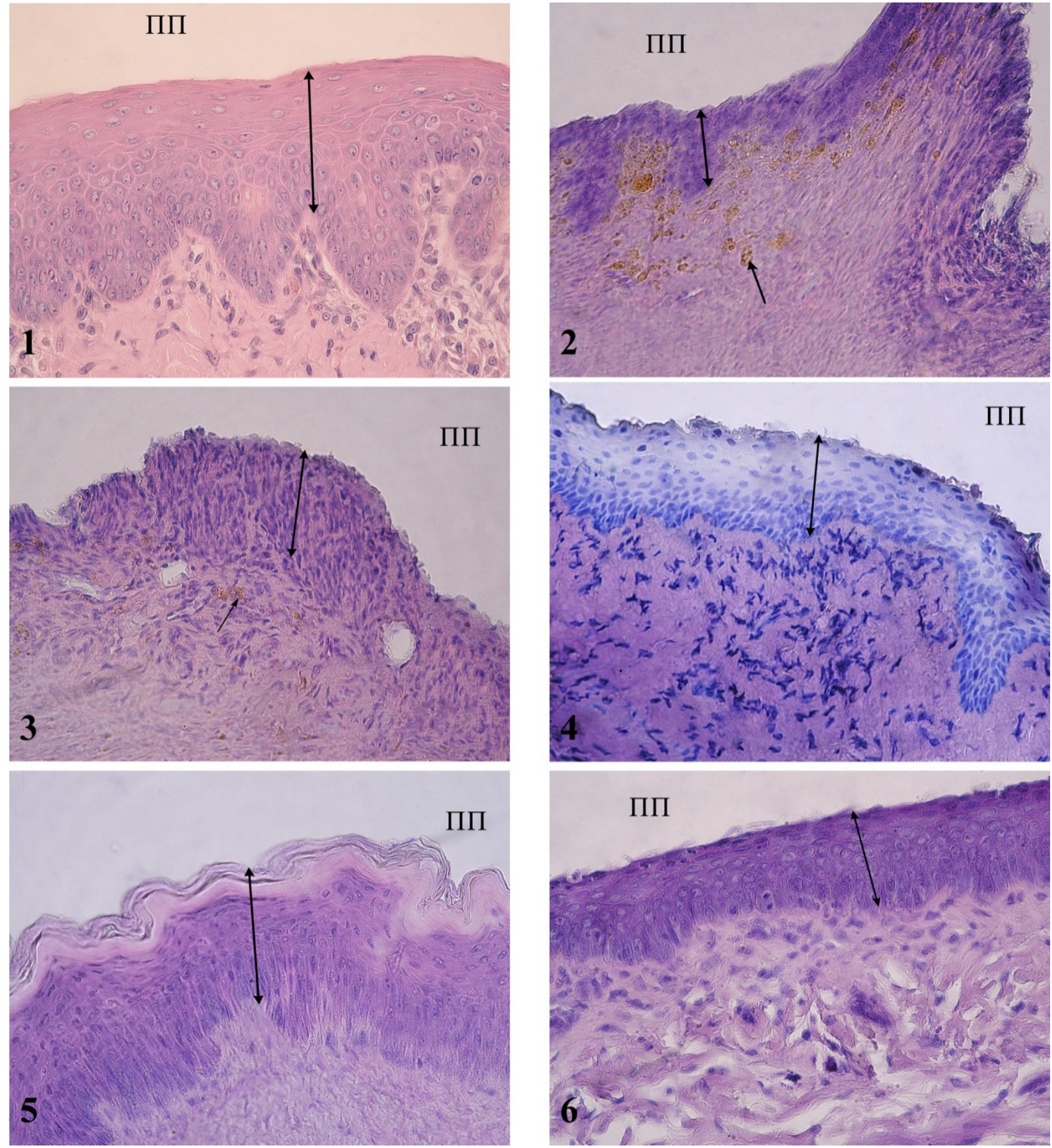

Рис. 1. Гістологічні зміни слизової оболонки піхви контрольних та експериментальних груп на моделі травматичного вагініту.

Примітка: 1 - контроль: непошкоджена епітеліальна пластинка; 2,3 - ТВ - пошкодження епітеліальної пластинки, гемосидерин; 4 - ТВ+О: частково збережений епітелій, збільшення щільності фрібробластів у власній пластинці слизової оболонки; 5 - ТВ+ДП: часткове збереження епітеліальної пластинки слизової оболонки, зроговіння поверхневих шарів епітелію; 6 - ТВ+РП: часткове збереження слизової оболонки; ПП - просвіт піхви; ↔ товщина слизової оболонки; $\leftarrow$ гемосидерин. Забарвлення гематоксиліном та еозином, ×400.

нок піхви. Реєстрували різке кровонаповнення окремих судин, рідше крововиливи, що вказує на зменшення перфузії регіонарних судин.
У таблиці 2 наведено результати морфометричної оцінки структурних змін піхви. Мікроскопічне дослідження вказує на домінування набряку слизової обо-

ISSN 2312-0967. Pharmaceutical review. 2019. № 1 
Фармакологічні дослідження біологічно активних речовин Pharmacological researches of biologically active substances

Таблиця 2. Результати гістологічної та морфометричної оцінки структурних змін піхви на моделі травматичного вагініту

\begin{tabular}{|c|c|c|c|c|c|}
\hline \multirow{3}{*}{ № } & \multirow{3}{*}{ Група } & \multicolumn{4}{|c|}{ Рівень пошкодження } \\
\hline & & \multicolumn{2}{|c|}{ Бали } & \multicolumn{2}{|c|}{$\begin{array}{c}\text { Товщина епітеліальної пластинки слизової } \\
\text { оболонки, мкм }\end{array}$} \\
\hline & & Me [Q1-Q2] & Значення P & Me [Q1-Q2] & Значення Р \\
\hline 1 & Контроль & 0 & - & $147,9[136,1-176,5]$ & - \\
\hline 2 & TB & $8[6,5-10,5]$ & $\mathrm{P}_{1-2}<0,05$ & $55,5[36,4-75,7]$ & $\mathrm{P}_{1-2}<0,05$ \\
\hline 3 & $\mathrm{~TB}+\mathrm{O}$ & $4[3-6]$ & $\begin{array}{l}\mathrm{P}_{1-2}<0,05 \\
\mathrm{P}_{2-3}<0,05\end{array}$ & $46,7[37,29-77,0]$ & $\begin{array}{l}\mathrm{P}_{1-2}<0,05 \\
\mathrm{P}_{2-3}>0,05\end{array}$ \\
\hline 4 & ТВ+ДП & $6[3,5-6,5]$ & $\begin{array}{l}P_{1-2}<0,05 \\
P_{2-4}<0,05\end{array}$ & $109,8[51,6-204,0]$ & $\begin{array}{l}P_{1-2}<0,05 \\
P_{2-4}<0,05\end{array}$ \\
\hline 5 & TB+PП & $4[3,5-7]$ & $\begin{array}{l}\mathrm{P}_{1-2}<0,05 \\
\mathrm{P}_{2-5}<0,05\end{array}$ & $79,9[58,4-117,9]$ & $\begin{array}{l}\mathrm{P}_{1-2}<0,05 \\
\mathrm{P}_{2-5}<0,05\end{array}$ \\
\hline
\end{tabular}

лонки та гіперемії судин у розвитку порушень. Товщина епітеліальної пластинки становила 55,5[36,4$75,7]$ мкм, що статистично значуще менше від контрольних значень у 2,6 раза $(p<0,05)$.

У групі ТВ+О встановлено структурні зміни, які описано у групі 2, але спостерігали деякі відмінності. Епітелій характеризувався більшим ступенем збереження, зменшенням набряку, гіперемією судин. Реєстрували ділянки відносно непошкодженого епітелію та осередки регенерації (збільшення щільності епітеліоцитів у базальному шарі епітеліальної пластинки). У власній пластинці також відмічено осередки гемосидерину і стазовані судини. Товщина епітеліальної пластинки становила 46,7[37,29-77,0] мкм і не відрізнялась від групи 2. При цьому встановлено статистично значуще зменшення кількості балів, які нараховані за критеріями структурних змін $(\mathrm{P}<0,05)$. Результати вказують лише на часткове збереження слизової оболонки та ініціацію відновного процесу.

У групі ТВ+ДП встановлено більший ступінь збереження епітелію. Головними структурними проявами були набряк і локальна втрата епітеліальної пластинки, рівною мірою зменшення щільності осередків гіперемії судин і крововиливів. Структурними проявами відновного процесу були пролісреративні зміни у базальному шарі епітеліальної пластинки і збільшення щільності фрібробластів у власній пластинці слизової оболонки. Встановлено статистично значуще зменшення кількості балів за оцінюваними критеріями $(\mathrm{P}<0,05)$. Товщина епітелію становила 109,8[51,6$204,0]$ мкм, що вірогідно більше від групи 2 на 97,8 \% $(\mathrm{P}<0,05)$, але не досягали контрольних значень (у середньому менше на $34,6 \%, \mathrm{P}<0,05)$. Результати вказують на позитивний вплив ДП на стан слизової оболонки піхви за умов ТВ.

У групі ТВ+РП фрармакологічну дію на слизову оболонку оцінювали за ступенем зменшення гіперемії судин та запальної реакції. В окремих випадках відмічено інсрільтрацію лейкоцитів у просвіт органа, а також зроговіння поверхневих шарів епітелію (ознаки зроговіння виявлено і у групі з ДП). Результати морфометрії епітеліальної пластинки засвідчили часткове відновлення слизової оболонки піхви при застосуванні РП. Товщина епітелію становила 79,9[58,4117,9] мкм, що вірогідно більше від групи 2 на 43,9 \% $(\mathrm{P}<0,05)$, але не досягали контрольних значень (в середньому менше на 85,1\%, $\mathrm{P}<0,05)$.

На основі результатів мікроскопічного та морфрометричного досліджень зроблено висновок про сприяння відновленню слизової оболонки піхви при застосуванні ДП і РП на моделі травматичного вагініту. За даними морфометрії та оцінки структурних змін піхви за обраними вірогідної різниці між дією ДП і РП на моделі ТВ не встановлено, спостерігалася лише тенденція до відновного процесу при введенні ДП. На основі результатів зроблено висновки про сприятливу дію ібупрофену у комплексі з протимікробними засобами щодо запобігання деструктивним змінам слизової оболонки піхви та активації репаративної регенерації.

3 клінічних досліджень відомо, що терапевтична дія ібупрофену полягає у зменшенні симптомів вагініту (свербіння, болю, печії, еритеми та почервоніння піхви) після 3 днів лікування і $є$ більш ефективним порівняно з іншими протизапальними засобами, наприклад бендизаміном [14]. Ібупрофен неселективно пригнічує циклооксигенезу (COX-1 і COX-2), що зменшує утворення простагландинів та тромбоксану А2 у місці запалення і тим самим зменшує розвиток запалення, інфрільтрацію лейкоцитів, тромбоз судин. Ібупрофен і клотримазол добре переносяться при інтравагінальному введенні, тоді як метронідазол у високих дозах може мати негативні і побічні дії [15]. У зв'язку з цим означена комбінація досліджуваного засобу (ібупрофрен, клотримазол, метронідазол) у вигляді супозиторіїв може сприяти зменшенню побічної дії при місцевому застосуванні, крім того, розробка таких засобів у фрормі вагінальних супозитиріїв дозволяє місцево до-

ISSN 2312-0967. Фармацевтичний часопис. 2019. № 1 
Фармакологічні дослідження біологічно активних речовин Pharmacological researches of biologically active substances

ставити лікарський засіб [16], не подразнює слизову оболонку піхви і за даними літератури має ефективність як при пероральному застосуванні [17].

Висновки. Потенційний лікарський засіб у вигляді вагінальних супозиторіїв, до складу якого входять ібупрофрен, клотримазол та метронідазол, сприяє відновленню слизової оболонки піхви у тварин з експериментальним травматичним вагінітом. При дії комбінованих супозиторіїв збільшується щільності фрібробластів у власній пластинці і активується репара- тивна регенерація епітеліальної пластинки, що проявлялося у статистично значущому збільшенні їі товщини. За даними морфометрії та кількісної оцінки структурних змін (набряк слизової оболонки, гіперемія судин, крововиливи, лейкоцитарні інсрільтрати) досліджуваний засіб не поступається референтному засобу Нео-Пенотран®.

Конфлікт інтересів: відсутній.

Conflicts of interest: author has no conflict of interest to declare.

\title{
ИССЛЕДОВАНИЕ ВЛИЯНИЯ ПОТЕНЦИАЛЬНОГО ЛЕКАРСТВЕННОГО СРЕДСТВА С ПРОТИВОВОСПАЛИТЕЛЬНОЙ И ПРОТИВОМИКРОБНОЙ АКТИВНОСТЬЮ НА СТРУКТУРНЫЕ ИЗМЕНЕНИЯ СЛИЗИСТОЙ ОБОЛОЧКИ ВЛАГАЛИЩА НА МОДЕЛИ ТРАВМАТИЧЕСКОГО ВАГИНИТА
}

\author{
Л. В. Онищук, И. В. Ниженковская, С. И. Савосько \\ Национальный медицинский университет имени А. А. Богомольца, Киев \\ lucy.on04@gmail.com
}

Цель работы. Исследовать структурные изменения слизистой оболочки влагалища крыс после моделирования травматического вагинита и влияния комбинированных суппозиторий с противовоспалительной и противомикробной активностью.

Материалы и методы. Животным воспроизводили модель травматического вагинита, после чего во влагалище вводили исследуемые лекарственные средства в виде суппозиторий. Исследуемый потенциальный препарат содержал ибупрофен, клотримазол и метронидазол в фрорме суппозиторий. Нео-Пенотран® (препарат сравнения), в состав котрого входит миконазол и метронидазол. Оба лекарственные средства включали идентичную основу - витепсол. Материалами исследования были образцы влагалища крыс, которые были отобраны для гистологического исследования.

Результаты и обсуждение. При моделировании травматического вагинита у крыс наблюдали дистрофические изменения эпителиоцитов и уменьшение толщины слизистой оболочки влагалища, гиперемию сосудов, инорильтрацию лейкоцитов, в меньшей степени регенерации. Введение исследуемого потенциального лекарственного средства и препарата сравнения положительно повлияло на восстановительные процессы слизистой оболочки влагалища. Структурными проявлениями восстановительного процесса были пролиферативные изменения в эпителии и увеличение плотности фибробластов в собственной пластинке слизистой оболочки. Установлено статистически значимое увеличение толщины эпителия.

Выводы. Сделан вывод о предотвращении дистрофических изменений влагалища при применении исследуемого лекарственного средства и препарата сравнения на модели травматического вагинита, протекторное действие в отношении эпителия слизистой оболочки влагалища и противовоспалительное действие ибупрофрена в комплексе с противомикробными средствами.

Ключевые слова: травматический вагинит; структурные изменения; слизистая оболочка; суппозитории.

\section{RESEARCH OF THE EFFECT OF A POTENTIAL MEDICINAL PRODUCT WITH ANTI-INFLAMMATORY AND ANTIMICROBIAL ACTIVITY ON STRUCTURAL CHANGES IN THE VAGINAL MUCOSA ON THE MODEL OF TRAUMATIC VAGINITIS}

\author{
L. V. Onyshchuk, I. V. Nizhenkovska, S. I. Savosko \\ O. Bohomolets National Medical University, Kyiv \\ lucy.on04@gmail.com
}

The aim of the work. Exploring structural changes in the mucous membrane of the vagina of the rats after the simulation of traumatic vaginitis and the effect of the combined suppository with anti-inflammatory and antimicrobial activity. Materials and Methods. Animals were reproduced the model of traumatic vaginitis, after which the investigated drugs were introduced into the vagina in the form of a suppository. The investigated potential medicinal product contained ibuprofen,

ISSN 2312-0967. Pharmaceutical review. 2019. № 1 
Фармакологічні дослідження біологічно активних речовин Pharmacological researches of biologically active substances

clotrimazole and metronidazole in the form of suppositories. Neo-Penotran ${ }^{\circledR}$ (Comparative drug) in its composition had miconazole and metronidazole. Both drugs included an identical basis - witepsol. The study material was the samples of the vagina of the rats, which were selected for histological examination.

Results and Discussion. In the simulation of traumatic vaginitis in rats, dystrophic changes in epithelial cells and a decrease in the thickness of the vaginal mucosa, vascular hyperemia, leukocyte infiltration, and, to a lesser extent, regeneration were observed. The introduction of the investigated potential medicinal product and the comparator product positively influenced the recovery processes of the vaginal mucus. The structural manifestations of the restorative process were proliferative changes in the epithelium and an increase in the density of fibroblasts in their own plate of the mucous membrane. A statistically significant increase in the thickness of the epithelium is established.

Conclusions. A conclusion is made on the prevention of dystrophic vaginal changes in the use of the investigational medicinal product and the comparison product on the model of traumatic vaginitis, the tread effect on the epithelium of the vaginal mucosa and the anti-inflammatory effect of ibuprofen in combination with antimicrobial agents.

Key words: traumatic vaginitis; structural changes; mucous membrane; suppositories.

\section{Список літератури}

1. Isolation of different species of Candida in patients with vulvovaginal candidias is from sari / Z. Taheri, T. Galinimoghadam, S. R. Aghili [et al.] // Jundishapur Journal of Microbiology. - 2015. - No. 8 (4). - Mode access : http:// doi.org/10.5812/jjm.8(4)2015.15992

2. Use of locally delivered dequalinium chloride in the treatment of vaginal infections: a review / E. R. Weissenbacher, S. Gerber, V. Prasauskas, P. Grob // Archives of Gynecology and Obstetrics. - 2016. - No. 293. - P. 469-484.

3. Vaginitis candida albicans of vaginal dendritic cells in a rat model of phenotypic and functional characterization / R. Lucciarini, M. Boccanera, C. Amantini [et al.] // Infection and Immunity. - 2006. - No. 74 (7). - P. 4282-4294.

4. Protective role of antimannan and anti-aspartyl protein as eantibodies in an experimental model of Candida albicans vaginitis in rats / M. Boccanera, D. Adriani, E. Spreghini [et al.] // Infection and Immunity. - 1997. - No. 65 (8). - P. 3399-3405.

5. Dolzhykova O. V. Pathomorpological research of vaginal suppositories "klimedeks" in rats with the irrytative vaginitis / L. M. Maloshtan, O. V. Dolzhykova // Ukrainian Biopharmaceutical Journal. - 2016. - No. 6 (47). - P. 30-36.

6. Nizhenkovska I. V. In vitro susceptibility study of candida spp. isolates to new combined potential medicinal product for the treatment of vaginal candidiasis / L. V. Zinchenko, I. V. Nizhenkovska // ScienceRise. - 2018. - No. 1(11). P. 47-52.

7. Gülmezoglu A. M. Interventions for trichomoniasis in pregnancy / A. M. Gülmezoglu, M. Azhar // Cochrane Database Syst. Rev. - 2011. - No. 11 (5).

8. Bradshaw C. S. Current treatment of bacterial vaginosis limitations and need for innovation / J. D. Sobel // The Journal of Infectious Diseases. - 2016. - No. 214 (Suppl. 1). - P. 14-20.

9. Milani M. Vaginal use of ibuprofen isobutanolammonium (Ginenorm): Efficacy, tolerability, and pharmacokinetic data: A review of available data / M. Milani, P. Iacobelli //
ISRN Obstetrics and Gynecology. - 2012. - Mode access : doi:10.5402/2012/673131.

10. Schnitzer T. J. Comparison of lumiracoxib with naproxen and ibuprofen in the Therapeutic Arthritis Research and Gastrointestinal Event Trial (TARGET), reduction in ulcer complications: randomised controlled trial / T. J. Schnitzer, G. R. Burmester, E. Mysler // Lancet. 2004. - No. 364 (9435). - P. 665-674.

11. Nizhenkovska I. V. Acute toxicity study of a new complex drug with anti-inflammatory activity / I. V. Nizhenkovska, L. V. Zinchenko // Current Topics in Pharmacology. 2017. - No. 21. - P. 71-74.

12. Efficacy and safety of topical diclofenac containing dimethylsulfoxide (DMSO) compared with those of topical placebo, DMSO vehicle and oral diclofenac for knee osteoarthritis / L. S. Simon, L. M. Grierson, Z. Naseer [et al.] // Pain. - 2009. - No. 143 (3). - P. 238-245.

13. Методы экспериментального изучения биологически активных веществ на моделях вульвовагинита. Методические рекомендации / С. М. Дроговоз, А. Г. Цыпкун, В. В. Решетняк [и др.]. - К. : «Авицена», 2003 - 19 С.

14. Pullè $C$. Clinical trial comparing the activity and efficacy of Ibuprofen isobutanol ammonium vs Benzydamine hydrochloride, appliedas vaginal irrigations, in patients with vaginitis / E. Sturlese // Clinical and Experimental Obstetrics and Gynecology. - 2002. - No. 29 (3). - P. 173-179.

15. Micronucleus induction by metronidazole in rat vaginal mucosa / J. M. Ornelas-Aguirre, B. C. Gómez-Meda, A. L. Zamora-Perez [et al.] // Environ. Mol. Mutagen. 2006. - No. 47 (5). - P. 352-356.

16. Advanced topical drug delivery system for the management of vaginal candidiasis / S. J. Himmat, G. Tarun, R. Goutam, K. G. Amit // Drug Delivery. - 2016. - No. 23. - P. 550-563.

17. A pilot study of metronidazole vaginal gel versus oral metronidazole for the treatment of Trichomonas vaginalis vaginitis / J. A. Mcgregor, M. Ismail, W. M. Mccormack // Sex Trans. Dis. - 1998. - No. 25. - P. 176-179.

ISSN 2312-0967. Фармацевтичний часопис. 2019. № 1 
Фармакологічні дослідження біологічно активних речовин Pharmacological researches of biologically active substances

\section{References}

1. Hedayati MT, Taheri Z, Galinimoghadam T, Aghili SR, Yazdani Cherati J, Mosayebi E. Isolation of different species of Candida in patients with vulvovaginal candidiasis from sari. Jundishapur J Microbiol. 2015;8(4). DOI:10.5812/ jjm.8(4)2015.15992

2. Mendling W, Weissenbacher ER, Gerber S, Prasauskas V, Grob P. Use of locally delivered dequalinium chloride in the treatment of vaginal infections: a review. Arch Gynecol Obstet. 2015;293(3): 469-84.

3. De Bernardis F, Lucciarini R, Boccanera M, et al. Phenotypic and functional characterization of vaginal dendritic cells in a rat model of Candida albicans vaginitis. Infect Immun. 2006;74(7): 4282-94.

4. De Bernardis F, Boccanera M, Adriani D, Spreghini E, Santoni G, Cassone A. Protectiverole of antimannan and anti-aspartyl protein as eantibodies in an experimental model of Candida albicans vaginitis in rats. Infect Immun. 1997;65(8): 3399-405.

5. Dolzhykova OV, Maloshtan LM. Pathomorpological research of vaginal suppositories "Klimedeks" in rats with the irrytative vaginitis. Ukrainian Biopharm J 2016;6(47): 30-6. 6. Nizhenkovska IV, Zinchenko LV. In vitro susceptibility study of candida spp. isolates to new combined potentia medicinal product for the treatment of vaginal candidiasis. Science Rise. 2018;1(11): 47-52.

7. Gülmezoglu AM, Azhar M. Interventions for trichomoniasis in pregnancy. Cochrane Database Syst Rev. 2011;May11;(5):CD000220. doi: 10.1002/14651858. CD000220.pub2.

8. Bradshaw CS, Sobel JD. Current treatment of bacterial vaginosis-limitations and need for innovation. $J$ Infect Dis. 2016;214(Suppl 1): 14-20.

9. Milani $M$, lacobelli P. Vaginal use of ibuprofen isobutanolammonium (ginenorm): Efficacy, tolerability, and pharmacokinetic data: A review of available data. ISRN Obstet Gynecol. 2012; 673131. doi:10.5402/2012/673131
10. Schnitzer TJ, Burmester GR, Mysler E, etal. Comparison of lumiracoxib with naproxen and ibuprofen in the Therapeutic Arthritis Research and Gastrointestinal Event Trial (TARGET), reduction in ulcer complications: randomised controlled trial. Lancet. 2004;364(9435): 665-74.

11. Nizhenkovska IV, Zinchenko LV. Acute toxicity study of a new complex drug with anti-inflammatory activity. Curr Top Pharmacol. 2017;21: 71-4.

12. Simon LS, Grierson LM, Naseer Z, Bookman AA, Zev Shainhouse J. Efficacy and safety of topical diclofenac containing dimethylsulfoxide (DMSO) compared with those of topical placebo, DMSO vehicle and oral diclofenac for knee osteoarthritis. Pain. 2009;143(3): 238-45.

13. Drogovoz SM, Tsypkun AG, Reshetnyak VV. Methods of experimental study of biologically active substances on models of vulvovaginitis. Guidelines. [Методы экспериментального изучения биологически активных веществ на моделях вульвовагинита. Метод рекомендации] Kyiv: Avitsena; 2003. Russian.

14. Pullè $\mathrm{C}$, Sturlese $\mathrm{E}$. Clinical trial comparing the activity and efficacy of Ibuprofen isobutanol ammonium vs Benzydamine hydrochloride, appliedas vaginal irrigations, in patients with vaginitis. Clin Exp Obstet Gynecol. 2002;29(3): 173-9.

15. Ornelas-Aguirre JM, Gómez-Meda BC, ZamoraPerez AL, Ramos-Ibarra ML, Batista-González CM, ZúñigaGonzález GM. Micronucleus induction by metronidazole in rat vaginal mucosa. Environ Mol Mutagen. 2006;47(5): 352-6.

16. Johal HS, Garg T, Rath G, Goyal AK. Advanced topical drug delivery system for the management of vaginal candidiasis. Drug Deliv. 2016;23(2): 550-63.

17. Mcgregor JA, Ismail M, Mccormack WM. A pilot study of metronidazole vaginal gel versus oral metronidazole for the treatment of Trichomonas vaginalis vaginitis. Sex Trans Dis. 1998;25(3): 176-179.

Надійшла до редакції / Received: 19.11.2018 Після доопрацювання / Revised: 10.12.2018, 15.02.2019 Прийнято до друку / Accepted: 20.02.2019

\section{Відомості про авторів:}

Онищук Л.В. - асистент каф. фрармацевтичної, біологічної та токсикологічної хімії, Національний медичний університет імені О.О. Богомольця, Київ, Україна. E-mail: lucy.on04@gmail.com, ORCID 0000-0002-7479-868X

Ніженковська І.В. - д. мед. Н., професор, зав. каф. фрармацевтичної, біологічної та токсикологічної хімії, Національний медичний університет імені О.О. Богомольця, Київ, Україна. E-mail: dekan-farm@ukr.net, ORCID 00000001-5065-3147

Савосько C.І. - канд. біол. наук, асистент кафр. гістології та ембріології Національного медичного університету імені O.О. Богомольця, Київ, Україна. E-mail: savosko_s@ukr.net, ORCID 0000-0001-5145-2195

\section{Information about authors:}

Onyshchuk L.V. - assistant of the Pharmaceutical, Biological and Toxicological Chemistry Department, O.O. Bohomolets National Medical University, Kyiv, Ukraine. E-mail: lucy.on04@gmail.com, ORCID 0000-0002-7479-868X

Nizhenkovska I.V. - DS (Medicine), Professor, head of the Pharmaceutical, Biological and Toxicological Chemistry Department, O.O. Bohomolets National Medical University, Kyiv, Ukraine. E-mail: dekan-farm@ukr.net, ORCID 0000-00015065-3147

Savosko S.I. - PhD (Biology), Assistant of the Histology and Embryology Department, O.O. Bohomolets National Medical University, Kyiv, Ukraine. E-mail: savosko_s@ukr.net, ORCID 0000-0001-5145-2195

ISSN 2312-0967. Pharmaceutical review. 2019. № 1 